\title{
Studies on the Toxins of Hemolytic Streptococci.
}

\author{
Fourth Report. \\ On the Immunological Properties of the Lethal Toxin.
}

$\mathrm{By}$

\section{Takesi Suganuma.}

(管沼武)

(From the Bacteriological Laboratory of Prof. $M$. Kuroya, Tohoku Imperial University, Sendai.)

\section{INTRODUCTION.}

With regard to the immunological properties of hemolytic streptococci, a great number of works have been hitherto published by many authors, such as Hopkins and Parker ${ }^{1)}$ Dochez, Avery and Lancefield $d^{2)}$, Cowan ${ }^{3)}$, Yoshioka), Killian ${ }^{5)}$, Cotoni and Césari6), Smith ${ }^{7}$, Andrewes ${ }^{8)}$, Lancefield and Todd ${ }^{9)}$, Parish and Okell10), Downie ${ }^{11)}$, Lyons and Ward ${ }^{12)}$, Griffith ${ }^{13)}$, Stamp ${ }^{14)}$, $\mathrm{Kana} \mathrm{e}^{15)}$ etc. and it has been made clear by them that the protection test performed with hemolytic streptococci of group " $\mathrm{A}$ " is quite typespecific. In particular, Lancefield and Todd emphasized that the immunization to hemolytic streptococci resulted from a type-specific substance which seemed likely to have some relation to the virulence, and it was antitoxic rather than antibacterial. The investigations on the immunological properties of the specific substance or of the fraction containing it have been relatively recently regarded as of great importance by $\mathrm{Hirsh}^{16)}$, Lash and $\mathrm{Kaplan}{ }^{17)}$, Hartle ${ }^{18)}, \mathrm{Smith}^{19)}$ and others. Particularly, it was Lancefiel $d^{20)}$ who made a great contribution to a rapid development in this direction by means of detailed immunological studies on the specific substance of hemolytic streptococci. She isolated M, C, P and $Y$ substances from bacterial bodies and made clear from chemical and immunological investigations that $M$ substance belonged to a protein and had a type specificity, that $\mathrm{C}$ substance was a carbohydrate and showed a species-specificity, that $P$ substance was a non-type-specific nucleoprotein and that $\mathrm{Y}$ substance was a non- 
type-specific protein. Furthermore, it was brought out clearly by Heidelberger and Kendall ${ }^{21)}$, Flosdorf and Chambers ${ }^{22)}$,

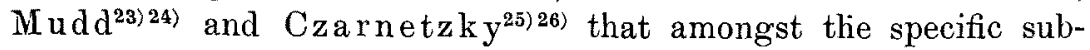
stances, one of a protein nature played immunologically an important role. In recent years it has been emphasized that an acid soluble protein has an immunologically important significance. Stamp and Hendr ${ }^{27)}$ demonstrated that the acid soluble protein obtained from. group " $A$ " and " $C$ " was a mouse-protective antigen and had the nature of whole antigen. In addition, $\mathrm{Koda} \mathrm{ma}^{28)}$ reported that the specific protein fraction of group "A" streptococci was the most important antigen for human subjects and animals, that it was a typespecific antigen and an allergen at the same time, and further, that the acid soluble protein isolated from the young culture of this microörganism was able to produce the protective antibodies in mice, but he did not discuss the toxicity of this substance for animals.

As above mentioned, there are numerous immunological studies of hemolytic streptococci, but the immunological properties of the lethal toxin has not been studied, except that Weld ${ }^{29}$ hinted at the absence of antigenicity in the lethal component. Since the lethal toxin isolated by me is an acid soluble protein, it will provide interest to investigate its immunological properties.

\section{Precipitation in Homologous Antibacterial Serum Before and After Absorption with Each Fraction.}

\section{(1) Precipitation Before Absorption.}

Antibacterial serum was prepared according to the following procedure; the cultures on blood agar slants were suspended with physiological salt solution and heated to $60^{\circ} \mathrm{C}$. for 30 minutes in order to kill the bacteria, and then injected intravenously into rabbits with a repose of 6 days. The amount injected was a half slant in the first week, one slant in the second, two slants in the third, three slants in the fourth, and four slants in the fifth. On the seventh day after the last injection a small amount of blood was taken up in order to test the titer of agglutinins for bacterial cells. Since it was confirmed by this test that immune bodies were formed in a considerably high degree, the rabbits were bled entirely.

The neutral physiological salt solutions of each fraction were prepared in progressive dilutions, and these diluted solutions were piled on the original antibacterial sera and the results were observed after two hours at room temperature. As given in Table 1, Fr. 1, the strongest lethal toxin, gave a positive precipitation in a dilution of $1: 200$, 
Fr. 2 in $1: 500$, Fr. 3 in $1: 2000$ and Fr. 4 in $1: 1000$. From the experimental data it is evident that the lethal toxin has a somewhat weak antigenicity in vitro. As control the physiological salt solution was piled on the antibacterial serum before and after absorption $\left(\mathrm{K}_{\mathbf{1}}\right)$, and the original solution of each fraction was piled on the normal rabbit serum $\left(\mathrm{K}_{2}\right)$ and their results were all negative.

\section{TABLE 1.}

Precipitation in homologous antibacterial serum before and after absorption with each fraction.

\begin{tabular}{|c|c|c|c|c|c|c|c|}
\hline \multirow{2}{*}{\multicolumn{2}{|c|}{$\begin{array}{l}\text { Antibacterial } \\
\text { serum } \\
\text { Antigen } \\
\text { (Each fracti in) }\end{array}$}} & \multirow{2}{*}{$\begin{array}{l}\text { Unabsorb- } \\
\text { ed }\end{array}$} & \multicolumn{4}{|c|}{ Absorbed with } & \multirow{2}{*}{$\begin{array}{c}\text { Control } \\
\left(\mathrm{K}_{2}\right.\end{array}$} \\
\hline & & & Fr. 1 & Fr. 2 & Fr. 3 & Fr. 4 & \\
\hline Fr. 1 & $\begin{array}{lr}1: & 50 \\
1: & 100 \\
1: & 200 \\
1: & 500\end{array}$ & $\begin{array}{l}H \\
+ \\
+ \\
+\end{array}$ & $\begin{array}{l}- \\
- \\
-\end{array}$ & $\begin{array}{l} \pm \\
\pm \\
-\end{array}$ & $\begin{array}{l}H \\
+ \\
-\end{array}$ & $\begin{array}{l}+ \\
+ \\
\pm \\
-\end{array}$ & - \\
\hline Fr. 2 & $\begin{array}{rr}1: & 50 \\
1: & 100 \\
1: & 200 \\
1: & 500 \\
1: & 1000\end{array}$ & $\begin{array}{l}H \\
+ \\
+ \\
+ \\
+\end{array}$ & $\begin{array}{l}+ \\
\pm \\
\pm \\
-\end{array}$ & $\begin{array}{l} \pm \\
\pm \\
- \\
- \\
-\end{array}$ & $\begin{array}{l}+ \\
+ \\
\pm \\
-\end{array}$ & $\begin{array}{l}+ \\
+ \\
\pm \\
-\end{array}$ & - \\
\hline Fr. 3 & $\begin{array}{lr}1: & 50 \\
1: & 100 \\
1: & 200 \\
1: & 500 \\
1: & 1000 \\
1: & 2000 \\
1: & 5000\end{array}$ & $\begin{array}{l}\text { H } \\
+ \\
+ \\
+ \\
+ \\
+ \\
+ \\
-\end{array}$ & $\begin{array}{l}H \\
H \\
+ \\
+ \\
\pm \\
-\end{array}$ & $\begin{array}{l}+ \\
+ \\
+ \\
+ \\
\pm \\
=\end{array}$ & $\begin{array}{l}+ \\
\pm \\
\pm \\
- \\
- \\
-\end{array}$ & $\begin{array}{l}H \\
H \\
+ \\
\pm \\
= \\
-\end{array}$ & - \\
\hline Fr. 4 & $\begin{array}{lr}1: & 50 \\
1: & 100 \\
1: & 200 \\
1: & 500 \\
1: & 000 \\
1: 2 & 000\end{array}$ & $\begin{array}{l}H \\
+1 \\
+ \\
+1 \\
+ \\
-\end{array}$ & $\begin{array}{l}+ \\
+ \\
+ \\
+ \\
\pm \\
\end{array}$ & $\begin{array}{l}4 \\
+ \\
+ \\
+ \\
-\end{array}$ & $\begin{array}{l}+ \\
+ \\
+ \\
\pm \\
-\end{array}$ & $\begin{array}{l}- \\
- \\
- \\
-\end{array}$ & - \\
\hline Contr & $\left(\mathrm{K}_{1}\right)$ & - & - & - & - & - & - \\
\hline
\end{tabular}

As control $\left(\mathrm{K}_{1}\right)$ the physiological salt solution was piled on the antibacterial serum.

As control $\left(\mathrm{K}_{2}\right)$ the original solution of each fraction was piled on the normal rabbit serum.

\section{(2) Precipitation After Absorption.}

The absorption of antibacterial serum was carried out as follows; 1 c.c. of immune serum was diluted with 1 c.c. of physiological salt solution. To the 
diluted serum 2 c.e. of 1 per cent neutral salt solution of each fraction was added respectively. The mixture was incubated for 2 hours at $37^{\circ} \mathrm{C}$. and then placed ovemight in an ice box. The precipitate was thrown down by centrifugalization and the clear supernatant serum was taken up. This procedure was repeated until the absorption became perfect. Testing whether the absorption was completely carried out at each repetition of this procedure, the absorption became complete after four repetitions in Fr. 1 and Fr. 4, but it was not perfect in Fr. 2 and Fr. 3, and so the absorptions with 4 per cent solutions of these two fractions further repeated 4 times, but the complete absorption still could not be performed, and the yields of Fr. 2 and Fr. 3 were too small to repeat any this procedure further.

The results of precipitin tests after absorption are given in Table 1. From the data it is known that the serum absorbed with each fraction, in spite of removing all precipitins for itself except Fr. 2 and Fr. 3, reacted still with other fractions in a somewhat lower dilution. In the serum absorbed with Fr. 1 the precipitins for Fr. 2 were absorbed in the highest degree, while those for Fr. 4 were scarcely absorbed at all. In the serum absorbed with Fr. 4 those for Fr. 3 were most absorbed, whereas those for Fr. 1 were hardly absorbed. (See Table 1)

\section{Precipitation of Each Fraction Isolated from Heterologous Bacteria.}

By the precipitation test with the above described antibacterial serum of each fraction (Fr. $1^{\prime}, \mathrm{Fr} .2^{\prime}, \mathrm{Fr} .3^{\prime}$ and Fr. $4^{\prime}$ ) isolated from another strain of streptococcus by means of the same process, which was ascertained to be a heterologous strain, it was brought out clearly as shown in Table 2 , that Fr. $2^{\prime}$ gave a positive result in dilution up to $1: 50$, Fr. $3^{\prime}$ in $1: 1000$ and Fr. $4^{\prime}$ in $1: 2000$, while Fr. $1^{\prime}$ showed no

TABLE 2.

Precipitation of each fraction isolated from heterologous bacteria.

\begin{tabular}{|c|c|c|c|c|c|c|c|c|c|}
\hline \multirow[b]{2}{*}{$\begin{array}{l}\text { Sort of } \\
\text { antigen }\end{array}$} & \multicolumn{7}{|c|}{ Dilution of antigen } & \multicolumn{2}{|c|}{ Control } \\
\hline & $\begin{array}{l}8 \\
20 \\
\because\end{array}$ & $\begin{array}{l}\stackrel{8}{0} \\
\dddot{2} \\
-\end{array}$ & $\begin{array}{l}\stackrel{\Xi}{3} \\
\ddot{\sim} \\
\end{array}$ & $\begin{array}{r}8 \\
: 5 \\
\because \\
-1 \\
\end{array}$ & $\begin{array}{l}\stackrel{8}{0} \\
\stackrel{0}{-1} \\
- \\
-\end{array}$ & \begin{tabular}{l}
$\stackrel{8}{\Xi}$ \\
$\vdots$ \\
\hdashline \\
-
\end{tabular} & $\begin{array}{l}8 \\
8 \\
\therefore \\
\because \\
-\end{array}$ & $K_{1}$ & $\mathrm{~K}_{2}$ \\
\hline Fr. $1^{\prime}$ & - & - & - & - & - & - & - & & - \\
\hline Fr. $2^{\prime}$ & + & - & - & - & - & - & - & - & - \\
\hline Fr. $3^{\prime}$ & $H$ & $H$ & H & + & + & - & - & & - \\
\hline Fr. $4^{\prime}$ & H & $H$ & H & + & + & \pm & - & & - \\
\hline
\end{tabular}

Cf. foot-note to Tabel 1 . 
positive precipitation, that is, Fr. $1^{\prime}$ gave no precipitation to heterologous antibacterial serum, whereas Fr. $4^{\prime}$ reacted with it. The fact indicates that Fr. 1 is a type specific substance, while Fr. 4 is a group specific one. (See Table 2)

\section{Agglutination in Homologous Antibacterial Serum Before and After Absorption with Each Fraction.}

Since the procedure of absorption could not be completeiy conducted with Fr. 2 and Fr. 3, only with the serum absorbed by Fr. 1 and Fr. 4 were the agglutination tests performed before and after absorption. Their results are shown in Table 3. The preparation of homogenous suspension of streptococci has been considered a matter of difficulty, but in this experiment the homogenous bacterial suspension was relatively easily prepared by means of antiformin as follows.

These microörganisms were cultivated for 8-12 hours in 0.5 per cent glucose bouillon and the relatively large particles were taken off by slight centrifugalization after thoroughly shaking the culture solntion. Then the apparently homogenously turbid solution was centrifuged sufficiently to precipitate the whole bacteria, and the clear supernatant was removed. The precipitated bacteria were washed twice with physiological salt solution, and finally a suitable amount of salt solution for the purpose of making a bacterial suspension was added. The suspension was thoroughly shaken in the shaking apparatus, and the homogenity of suspension was microscopically observed after introducing drop by drop 0.5 per cent antiformin and sufficient shaking in order to determine whether it was suitable to be employed. If it is still not enough homogenous for the experimental use by means of the procedure

TABLE 3.

Agglutination in homologous antibacterial serum before and after absorption with each fraction.

\begin{tabular}{|c|c|c|c|c|c|c|c|c|c|c|c|}
\hline \multirow[b]{2}{*}{$\begin{array}{l}\text { Antibacterial } \\
\text { serum }\end{array}$} & \multicolumn{11}{|c|}{ Agglutination in the diluted serum. } \\
\hline & $\begin{array}{l}8 \\
: \\
- \\
-\end{array}$ & $\begin{array}{l}8 \\
\vdots \\
\because \\
-\end{array}$ & $\begin{array}{l}\stackrel{8}{0} \\
\because \\
\sim \\
-1\end{array}$ & $\begin{array}{l}8 \\
\stackrel{8}{0} \\
\because \\
-\end{array}$ & $\begin{array}{l}8 \\
\infty \\
\because \\
-\end{array}$ & \begin{tabular}{l}
8 \\
0 \\
\hdashline \\
$\ddot{0}$ \\
\end{tabular} & 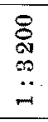 & $\begin{array}{l}\stackrel{8}{0} \\
\stackrel{7}{0} \\
\ddot{0} \\
\ddot{-1}\end{array}$ & $\begin{array}{l}8 \\
8 \\
\mathbf{0} \\
\dddot{1} \\
\ddot{-}\end{array}$ & $\begin{array}{l}8 \\
8 \\
0 \\
0 \\
0 \\
\because \\
-1\end{array}$ & \begin{tabular}{l}
$\overrightarrow{0}$ \\
\multirow{0}{4}{} \\
0 \\
0 \\
0
\end{tabular} \\
\hline Unabsorbed & $H$ & $H$ & H & H & $H$ & $H$ & $H$ & + & + & - & - \\
\hline $\begin{array}{l}\text { Absorbed with } \\
\text { Fr. } 1 \\
\text { Absorbed with } \\
\text { Fr. } 4\end{array}$ & $\begin{array}{l}H \\
H\end{array}$ & $\begin{array}{l}+ \\
H\end{array}$ & $\begin{array}{l}+ \\
+\end{array}$ & $\begin{array}{l}- \\
+\end{array}$ & $\begin{array}{l}- \\
H\end{array}$ & $\begin{array}{l}- \\
H\end{array}$ & $\begin{array}{l}- \\
H\end{array}$ & + & $\begin{array}{l}- \\
\pm\end{array}$ & - & - \\
\hline
\end{tabular}

,,++ \pm indicate the degrees of agglutination.

- indicates no agglutination. 
above described, it is better to employ the supernatant fluid after slight centrifugalization, or after quiet preservation in the cold for 24 to 48 hours. In this case it is necessary to give attention to the fact that the excess of antiformin dissolves the bacterial bodies and makes the suspension transparent.

The experimental data presented in Table 3 show that the absorption of antiserum with Fr. 1 removed the major part of agglutinins, as evidenced by the fact that the antiserum which agglutinated the organisms in dilution up to $1: 12800$ before absorption showed the agglutinin titer of $1: 200$ only after absorption, while the serum absorbed with Fr. 4 agglutinated almost in the same degree as before absorption, indicating that it is probably impossible to absorb the agglutinins with Fr. 4. (See Table 3)

\section{Protective Action of Homologous Antibacterial Serum Before and After Absorption with EACH FraCtion.}

Protection tests in mice of homologous antibacterial serum before and after absorption with Fr. 1 or Fr. 4 , which effected a complete absorption of precipitins for itself, were performed as follows.

The dilutions of the unabsorbed and absorbed serum, calculated on the basis of original serum were made ranging from $1: 10$ to $1: 100$. Then the bacterial suspension was prepared so as to contain a minimum lethal dose in 0.5 c.c. 15 minutes after the equal amounts of each diluted serum and bacterial suspension were thoroughly mixed, 1 c.c. of each mixed solution were injected intraperitoneally into mice weighing $10 \mathrm{gm}$. The minimum lethal dose of this microörganisms was $0.05 \mathrm{mgm}$. and it was previously ascertained that it was capable of killing all control mice. Mice alive and healthy during 7 days after inoculation were considered to be effectively protected and recorded as survivals.

The outcomes of protection tests show that the serum absorbed with Fr. 1 lost almost all protective power, while the same ability of antiserum absorbed with Fr. 4 was almost uninfluenced by this treatment, namely, it is impossible to absorb the protective power of antiserum with Fr.4. Furthermore, as 0.5 c.c. of antibacterial serum were injected togather with a minimum lethal dose (MLD $=0.5 \mathrm{mgm})$ of heterologous bacteria intraperitoneally into mice for the purpose of testing whether the antibacterial serum also has a protective power for heterologous bacteria, all mice died, showing that the protective antibody has evidently a type specificity. From the results of experiments above mentioned it is obvious that the lethal toxin is capable of absorb- 
ing almost all protective antibodies from the antibacterial serum. (See Table 4)

TABLE 4.

Protective action of homologous antibacterial serum before and after absorption with each fraction.

\begin{tabular}{c|c|c|c}
\hline \hline \multirow{2}{*}{$\begin{array}{c}\text { Dilution of } \\
\text { serum }\end{array}$} & \multicolumn{3}{|c}{ Mortality of mice. } \\
\cline { 2 - 3 } & Unabsorbed & Absorbed with \\
\hline $1: 100$ & $1 / 2$ & $2 / 2$ & Fr. 4 \\
$1: 50$ & $0 / 2$ & $2 / 2$ & $0 / 2$ \\
$1: 20$ & $0 / 2$ & $2 / 2$ & $0 / 2$ \\
$1: 10$ & $0 / 2$ & $2 / 2$ & $0 / 2$
\end{tabular}

$2 / 2$ indicates that out of 2 mice injected all 2 died. The route of injection: intraperitoneal.

VI. Antigenic Action of the Lethal Toxin in Mice.

In order to determine whether the lethal toxin is capable of bringing about an active immunity against an infection of homologous bacteria, the immunization by the lethal toxin in mice was carried out as follows.

During the first week each mouse received three doses of $0.01 \mathrm{mgm}\left(\frac{1}{10}\right.$ MLD) of Fr. 1, given intraperitoneally on three successive days, followed by four days' rest. During the second week each dose was raised to $0.02 \mathrm{mgm}$., and during the third week to $0.03 \mathrm{mgm}$. Each animal received a total of 0.18 $\mathrm{mgm}$. Seven days after the last injection, mice were tested for resistance to infection with homologous or heterologous strain. In order to determine the results of experiments, mice were kept under observation for seven days after infection.

Regarding with the protective power against intraperitoneal inoculation of homologous bacteria, as shown in Table 5, out of 5 mice immunized with Fr. 1, 4 mice survived for the inoculation of $2 \mathrm{MLD}$ of bacteria, showing 80 per cent survivors, while out of 5 mice immunized, 2 mice survived for the inoculation of $5 \mathrm{MLD}$, namely, it indicates 40 per cent survivors. As controls, it was ascertained that all untreated, healthy mice died by the inoculation of 2 MLD. From this outcome it is known that the lethal toxin has a protective antigenicity and can induce an active immunization, although it is not so in higher degree. On the other hand, I MLD of heterologous bacteria was inoculated into immunized mice for the purpose to reveal whether it is 
able to afford also a protection against the heterologous bacteria. In this test died all mice, showing that it had no protective activity against the heterologous bacteria, and so it is obviously type-specific. Then, in order to determine the probability of an active immunizing action not only against the living bacteria, but also against the lethal toxin itself, 2 MLD of Fr. 1 was injected intraperitoneally into mice immunized with Fr. 1. As presented in Table 5, all mice survived, showing the existence of an active immunity for the lethal toxin itself, while all mice injected with $5 \mathrm{MLD}$ of $\mathrm{Fr} .1$ were reduced to fatal issues. Therefore, it is evident that the lethal toxin is able to produce an immunity for itself in mice, although not in a remarkably high degree. (See Table 5)

TABLE 5.

Antigenic action of the lethal toxin (Fr. 1) in mice.

\begin{tabular}{c|c|c|c}
\hline & $\begin{array}{c}\text { Amount of injection } \\
\text { (per 10 gm.) }\end{array}$ & Treated mice & Control \\
\hline $\begin{array}{c}\text { Homologous living } \\
\text { bacteria }\end{array}$ & 2 MLD (0.1 mgm.) & $1 / 5$ & $2 / 2$ \\
Heterologous living & MLD (0.25 mgm. & $3 / 5$ & \\
bacteria & 1 MLD (0.5 mgm.) & $3 / 3$ & $2 / 2$ \\
\hline \multirow{2}{*}{ Fr. 1 } & 2 MLD (0.2 mgm.) & $0 / 3$ & $2 / 2$ \\
& 5 MLD (0.5 mgm.) & $3 / 3$ & \\
\hline
\end{tabular}

MLD = minimum lethal dose.

Cf. foot-note to Table 4.

VII. IMMUNOGENiCITY OF A.P.F.

(1) The Procedures of Immunization with A.P.F.

The minimum lethal dose of this fraction was $8 \mathrm{mgm}$. for a mouse weighing $10 \mathrm{gm}$, but since its $5 \mathrm{mgm}$. per $\mathrm{kgm}$ of body weight being

TABLE 6.

Procedure of immunization with A.P.F.

\begin{tabular}{|c|c|c|c|c|c|c|}
\hline \multirow{2}{*}{$\begin{array}{c}\text { Number of } \\
\text { rabbit }\end{array}$} & \multirow{2}{*}{ Body weight } & \multicolumn{5}{|c|}{ Amount of A.P.F. for injection per kgm of body weight } \\
\hline & & First & Second & Third & Fourth & Fifth \\
\hline No. 1 & $2450 \mathrm{gm}$ & 0.1 mgm. & $0.2 \mathrm{mgm}$. & $0.5 \mathrm{mgm}$. & $1 \mathrm{mgm}$. & $2 \mathrm{mgm}$. \\
\hline No. 2 & $2500 \mathrm{gm}$. & $n$ & $"$ & $"$ & $n$ & " \\
\hline No. 3 & $2900 \mathrm{gm}$ & 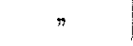 & $n$ & " & $n$ & $"$ \\
\hline
\end{tabular}

The route of injection: intravenous. 
injected intravenously into a rabbit, caused the animal to die 3 hours after injection, it became evident that its toxicity for rabbits was relatively high. The intravenous injection for immunization, therefore, was begun with a small amount and performed in the manner as shown in Table 6. The animals were bled 5 days after the last injection. (See Table 6)

\section{(2) Precipitation in Serum Immunized with A.P.F. Before and After Absorption with A.P.F.}

Performing the precipitation test with A.P.F. as above described, it became evident that the immune serum obtained from No. 3 rabbit showed the highest titer, positive until a dilution up to $1: 10000$. The absorption tests, therefore, were carried out with this immune serum. The procedures of absorption were as follows: 2. c.c. of 2 per cent physiological salt solution of A.P.F. were added to 2 c.c. of immune serum and incubated at $37^{\circ} \mathrm{C}$. for two hours. Then the precipitate was removed by centrifugalization and gently placed for twenty four hours in an ice box. To the supernatant serum 1 c.c. of 2 per cent solution of A.P.F. was further added, and then the same process was repeated.

The results of precipitation by the final absorbed serum with the variously diluted solution of A.P.F. are shown in Table 7. It is known from them that all precipitins were completely absorbed by this procedure. (See Table 7)

Table 7.

Precipitation in anti-A.P.F. serum before and after absorption with A.P.F.

\begin{tabular}{|c|c|c|c|c|c|c|c|c|c|c|c|}
\hline \multirow{2}{*}{ 焉 } & \multirow{2}{*}{ 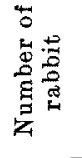 } & \multicolumn{10}{|c|}{ Precipitations with progressively diluted solutions of A.P.F. } \\
\hline & & \begin{tabular}{l}
$\circ 8$ \\
\hdashline \\
-
\end{tabular} & $\begin{array}{l}8 \\
\stackrel{0}{0} \\
-\end{array}$ & 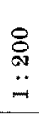 & $\begin{array}{l}8 \\
10 \\
-0 \\
-1\end{array}$ & $\begin{array}{l}8 \\
8 \\
-1 \\
-\end{array}$ & $\begin{array}{l}8 \\
8 \\
0 \\
\cdots \\
-1\end{array}$ & \begin{tabular}{l}
8 \\
8 \\
0 \\
\hdashline \\
-1
\end{tabular} & $\begin{array}{l}8 \\
8 \\
0 \\
0 \\
-\end{array}$ & $\begin{array}{l}8 \\
8 \\
8 \\
0 \\
\because \\
\end{array}$ & $\begin{array}{l}\overrightarrow{0} \\
0 \\
0 \\
0 \\
0\end{array}$ \\
\hline \multirow{3}{*}{$\begin{array}{l}\text { Unabsorb- } \\
\text { ed }\end{array}$} & No. 1 & H & tt & H & $H$ & $H$ & + & \pm & - & - & - \\
\hline & No. 2 & H & H & \# & $H$ & H & + & + & - & - & - \\
\hline & No. 3 & H & H & H & \# & H & + & + & + & - & - \\
\hline Absorbed & No. 3 & - & - & - & + & - & - & - & - & - & - \\
\hline
\end{tabular}

Cf. foot-note to Table 1.

\section{(3) Agglutination in Serum Immunized with A.P.F. Before and After Absorption with A.P.F.}

The outcomes of agglutinations of three immune sera above de- 
scribed are given in Table 8. It is evident from them that the degree of reaction was strongest in immune serum from rabbit No. 3 as in the case of precipitation. It gave a positive reaction in dilution up to $1: 800$ before absorption and remained in almost the same degree in spite of the absorption, demonstrating that the agglutinins were able to be scarcely absorbed by A.P.F. (See Table 8 )

TABLE 8.

Agglutination in anti-A.P.F. serum before and after absorption with A.P.F.

\begin{tabular}{|c|c|c|c|c|c|c|c|c|c|c|c|}
\hline \multirow{2}{*}{ 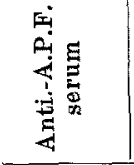 } & \multirow{2}{*}{ 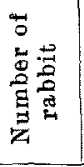 } & \multicolumn{10}{|c|}{ Agglutination in the diluted serum } \\
\hline & & $\begin{array}{l}20 \\
0 \\
\ddot{2} \\
-\end{array}$ & $\begin{array}{l}8 \\
\therefore \\
\ddot{2}\end{array}$ & $\begin{array}{l}8 \\
\ddot{9} \\
-\end{array}$ & $\begin{array}{l}8 \\
8 \\
0 \\
-\end{array}$ & \begin{tabular}{c}
$\stackrel{8}{8}$ \\
\hdashline \\
\hdashline
\end{tabular} & $\begin{array}{l}\mathscr{F} \\
\ddot{\infty} \\
\ddot{-}\end{array}$ & $\begin{array}{l}\mathscr{8} \\
8 \\
-1 \\
\because\end{array}$ & 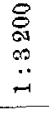 & $\begin{array}{l}8 \\
\stackrel{8}{*} \\
0 \\
\ddot{-}\end{array}$ & 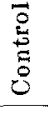 \\
\hline \multirow{3}{*}{$\begin{array}{l}\text { Unabsorb- } \\
\text { ed }\end{array}$} & No. 1 & $\mathrm{Ht}$ & $H$ & $H$ & + & + & - & - & $-\cdots$ & - & - \\
\hline & No. 2 & $\mathrm{HH}$ & $H$ & $1+$ & + & + & + & - & - & - & - \\
\hline & No. 3 & 車 & $H$ & $+t$ & + & + & + & \pm & - & - & - \\
\hline Absorbed & No. 3 & tt & $H$ & $t$ & + & + & + & \pm & - & $一$ & - \\
\hline
\end{tabular}

Cf, foot-note to Table 3.

\section{(4) Protective Action of Scrum Immunized with A.P.F.}

The protection tests were carried out as well as in the case of antibacterial serum above mentioned ; the immune serum was diluted, ranging from $1: 5$ to $1: 100$. Then the bacterial suspension was prepared so as to contain a minimum lethal dose in 0.5 c.c. 15 minutes after mixing equal amounts of each diluted serum and bacterial suspension, 1 c.c. of each mixture were injected intraperitoneally into mice weighing 10 gm.

Observing the results presented in Table 9, it will be seen that all mice were reduced to fatal issues. From this fact it is evident that the anti-A.P.F.immune serum has almost no ability to protect mice against death by infection of homologous bacteria. (See Table 9)

TABle 9.

Protective action of anti-A.P.F. sermm

\begin{tabular}{l|c|c|c|c|c}
\hline Dilution of serum & $1: 5$ & $1: 10$ & $1: 20$ & $1: 50$ & $1: 100$ \\
\hline Mortality of mice & $3 / 3$ & $3 / 3$ & $3 / 3$ & $3 / 3$ & $3 / 3$
\end{tabular}

Cf. foot-note to Table 4 . 


\section{Discussion.}

From the numerous works on the immunological properties of bacterial bodies and the specific substances isolated from them, it has been brought out clearly that substances of a protein nature, in particular the acid soluble protein, has an immunologically important significance. It is instructive, therefore, to pursue the immunological properties of the lethal toxin which belongs to an acid soluble protein. The precipitation of each fraction by antibacterial serum gave positive results in several degrees. In my former report it was confirmed that Fr. 1 belonged to an acid soluble protein, while Fr. 4 contained the largest amount of substances of a carbohydrate nature, and further that Fr. 2 and Fr. 3 corresponded to the intermediate substances between them. From this fact it was supposed that Fr. 1 might correspond to the M substance of Lancefield and Fr. 4 to the C substance of the same author. It is assumed, therefore, that the precipitation for Fr. 1 may be type-specific and that for Fr. 4 species-specific. Furthermore, from the experimental outcomes, that amongst each fraction isolated from another heterologous bacteria $\mathrm{Fr}$. $1^{\prime}$ corresponding to $\mathrm{Fr}$. 1 showed no precipitation to antibacterial serum, while Fr. $4^{\prime}$ corresponding to Fr. 4 indicated a remarkable precipitation to it, it is assumed that F. 1 has a type-specificity and Fr. 4 a species-specificity. The intensity of precipitation increased in the order of Fr. 1 to Fr. 3. From this fact it may be imagined that the intensity of precipitation for Fr. 4 ought to be stronger than that for Fr. 3, but it was not practically so. It is conceivable, however, that it is in all probability due to the co-existence of the non-antigenic substance of a carbohydrate nature in $\mathrm{Fr} .4$, which originated from the bouillon itself.

From the precipitation after absorption, it became evident that $\mathrm{Fr}$. 1 and Fr. 4 could absorb completely all precipitins for themselves, while it was possible to absorb only a small part of precipitins for other fractions. In view of the degree of absorption, it is known that Fr. 1 stands immunologically in the nearest relation to Fr. 2 and farthest from $\mathrm{Fr} .4$, while Fr. 4 comes nearest to Fr. 3 and farthest from Fr. 1. It is particularly interesting that the immunological relation of each fraction almost agrees with the correlation of toxicity and chemical properties of each fraction. From the agglutinations before and after absorption it is known that Fr. 1 could absorb the greater part of agglutinins, while Fr. 4 could scarcely absorb them. In a similar way with regard to the protective action of antibacterial serum, Fr. 1 could absorb almost all 
protective power, whereas Fr. 4 had no influence upon it. Furthermore, as from the experimental results the antibacterial serum was unable to show any protective power against heterologous bacteria, it became evident that the protective antibody has a type-specificity.

From the facts above described it is seen that the lethal toxin has obviously an antigenicity in vitro. In addition, the protection tests against the fatal infection indicate that the lethal toxin is capable of giving an active immunization for homologous type into mice, while it is unable to give any for heterologous type, that is to say, the protection tests are type-specific. These findings agree well with those of other authors. In comparison with the facts proved by A very and Goeb $\mathrm{l}^{30)}$ that acetylpolysaccharide isolated from pneumococcus type $I$ is a protective antigen for highly virulent bacteria in mice and has a type-specificity and can absorb completely all precipitins and agglutinins from antibacterial serum, it is most interesting that the lethal toxin, which may play a role as an important factor of virulence and belongs to a protein containing 14 per cent of nitrogen, has a type-specificity. Koda ma emphasized that the acid soluble protein isolated by him had a type-specificity and was a whole antigen, absorbing completely the protective antibodies for mice, agglutinins and precipitins from antibacterial serum. Since the lethal toxin has chemical and immunological properties similar to the specific protein of Kodama, it is conceivable that they may be at least similar substances, even if not the same, but it requires further detailed investigation to ascertain the difference from each other.

As above described, it is confirmed that the lethal toxin, which belongs to an acid soluble protein, has an immunologically important significance. Pursuing the immunological properties of A.P.F. for the purpose of making clear what immunological behaviour A.P.F. (an acid precipitable fraction) indicates, it has been brought out clearly that this fraction has also an antigenicity and an immunogenicity. From the facts that it is possible to absorb completely the precipitins, yet almost no agglutinin, and the immune serum with this fraction has almost no protective power against fatal infection, it is assumed that the immunological importance of A.P.F. may be somewhat inferior to that of the acid soluble protein, although it is impossible to say positively. These respects, however, will be made clear by further detailed investigations. 


\section{Summary.}

(1) The lethal toxin of hemolytic streptococcus has a type-specificity and is able to absorb the type-specific, mouse-protective antibodies, precipitins and the greater part of agglutinins from the homologous antibacterial serum.

(2) It can give a protective, active immunization and an antitoxic immunity into mice. This active immunization is type-specific.

(3) A.P.F. (acid precipitable fraction) has an antigenicity in vitro and an immunogenicity. It can absorb all precipitins, but almost no agglutinins from immune serum with this fraction, and this immune serum has no protective power against fatal infection.

In conclusion, I wish to thank Prof. M. K u ro ya for much valuable advice and criticism given in the course of this work.

\section{Reference.}

(1) Hopkins, J. G. a. Parker, J. T., J. Exp. Med., 1918, 27, 1.

(2) Dochez, A. R., Avery, O. T. a. Lancefield, R. C., J. Exp., Med., 1919, $30,179$.

(3) Cow a n, M. L., Brit. J. Exp. Path., 1924, 5, 226.

(4) Yoshioka, M., Z. f. Hyg., 1923, 97, 386, 408; 1924, 102, 179.

(5) Killi a n, H., Z. f. Hyg., 1925, 104, 489.

(6) Cotoni, L. a. Césari, E., Ann. Inst. Past., 1927, 41, 1270.

(7) Smith, J., J. Path. a. Bact., 1927, 30, 651.

(8) Andrewes, F. W., J. Path. a. Bact., 1928, 31, 132.

(9) Lancefield, R. C. a. Todd, E. W., J. Exp. Med., 1928, 48, 769.

(10) Parish, H. J. a. Oke 1l, C. C., Lancet, 1928, 214, 746.

(11) Downie, A. W., J. Path. a. Bact., 1930, 33, 563.

(12) Lyon s, C. a. Ward, H. K., J. Exp. Med., 1935, 61, 531.

(13) Griffith, F., J, Hyg., 1935, 34, 542.

(14) Stam p, T. C., Brit. J. Exp. Path., 1936, 17, 391.

(15) Ka nae, S., Saikingaku Zassi, 1923, No. 329, 413.

(16) Hirsh, E. F., J. Inf. Dis., 1925, 37, 523.

(17) Lash, A. F. a. Ka plan, B., J. Amer. Med. Assoe., 1926, 86, 1197.

(18) Hartley, P., Brit. J. Exp. Path., 1928, 9, 259.

(19) Smith, J., J. Path. a. Bact., 1929, 32, 401. 59,441

(20) Laneefield, R. C., J. Exp. Med., 1928, 47, 91, 469, 481; 1933, 57, 571; 1934,

(21) Heidelberger, M. a. Kendall, F. E., J. Exp. Med., 1931, 54, 515. J. Immun., 1936, 30, 267.

(22) Flosdorf, E. W. a. Chambers, L. A., J. Bact., 1936, 31, 570.

(23) Mudd, S., Czarnetzky, E. J., Pettit, H. a. Lack man, D., J. Bact., 1936, 31,571 .

(24) Mudd, S., Czarnetzks, E. J., Pettit, H. a. Flosdorf, E. W., J. Bact., $1937,33,63$.

(25) Czarnetzky, E. J., Lackmann, D., Pettit, H., Shaw, C. H. a. Mudd, S., J. Bact., 1937, 33, 64. 
(26) Caarnetzky, E. J., Pettit, H. a. Lackman, D., Proc. Amer. Philos. Soc., $1937,77,463$.

(27) Stam p, T. C. a. Hendry, E. B., Lancet, 1937, 232, 257.

(28) Kodama, T., Tokyo Izi Sinsi, 1936, 10; Saikingaku Zassi, 1937, No. 497, 433; Rinsho Naika, 1936, 2, 318; Kitasato Arch., 1936, 13, 101.

(29) Wel d, J. T., J. Exp. Med., 1934, 59, 83.

(30) Avery, 0. T. a. G oebel, W. F., J. Exp. Med., 1933, 58, 731. 